\title{
HIV-1 infection in a cohort of haemophilic patients
}

\author{
N Wagner, R Bialek, H Radinger, M Becker, K E Schneweis, H H Brackmann, D Niese
}

\begin{abstract}
The course of HIV infection in 53 haemophilic patients aged 5-20 years was evaluated by clinical examination and laboratory tests. During the evaluation time (median 30 months) two patients died of AIDS and 32 patients $(60 \%)$ deteriorated when assessed by the Brodt-Helm classification. Nineteen patients $(37 \%)$ had decreased absolute helper cell counts $(<500 \mathrm{CD} 4$ positive cells/ $\mu \mathrm{l})$, and 45 patients $(87 \%)$ had reduced helper cell to lymphocyte ratios $(<0.35)$. HIV-1 was isolated from peripheral lymphocytes in 29 of $\mathbf{4 6}$ patients. As the disease progressed the number of positive viral cultures increased. Considerable progression of the HIV infection was seen in haemophilic children and adolescents during the median evaluation period of 30 months. The transition from symptomless HIV infection to immunodeficiency was easily recognised.
\end{abstract}

A lowered ratio of helper cells to lymphocytes seems to be a useful marker of the beginning of the deterioration of the immune system.

During recent years the rate of HIV infection in children has increased. ${ }^{1-4}$ In addition to children of HIV infected mothers, and adolescents infected as a result of sexual intercourse or abuse of intravenous drugs, those with haemophilia were at risk as a result of treatment with clotting factor concentrates that had not been treated to inactivate viruses. ${ }^{5}$ Depending on the child's age, HIV affects different stages of the developing immune system. ${ }^{6}$ At the time of diagnosis the clinical features vary from a symptom free state to severe immunodeficiency. ${ }^{7}$ AIDS has a poor prognosis in children and adults of all risk groups, ${ }^{78}$ but there is controversy about the prognosis of HIV infection in haemophilic patients compared with other groups at risk (P Becker, et al. Abstract presented at the IV International Conference on AIDS, Stockholm 1988; JK Stehr-Green, et al. Abstract presented at the IV International Conference on AIDS, Stockholm, 1988). ${ }^{9-11}$

There are few European studies dealing with the course of HIV infection in haemophiliacs and even less about children and adolescents. ${ }^{12-14}$ In this paper we describe the course of HIV infection in 53 haemophilic children and adolescents.

Patients and methods

Of 155 haemophilic patients under 20 years of age who had been receiving commercial clotting factor concentrates for more than four years at the Institute for Experimental Haematology, 62 patients were seropositive for HIV infection in 1984 and 1985. Starting in March 1987, 53 of these 62 haemophilic children and adolescents aged 5-20 years (median 15 years) who were infected with HIV were followed up for 24-36 months (median 30 months). The boys were examined three to six times a year. Forty eight patients had haemophilia $A$ and five patients had haemophilia B; in all cases the haemophilia was classified as severe (factor VIII or IX $<1 \%$ ). Informed consent was obtained from the patients or their parents.

The following diagnostic procedures were carried out at three to six month intervals for each patient: clinical and neurological examination and laboratory tests including red cell count, white cell count, measurement of the erythrocyte sedimentation rate $(\mathrm{mm}$ in the first hour), liver function tests, and measurement of peripheral lymphocyte subpopulations by flow cytometry with commercial monoclonal antibody reagents (obtained from Ortho Diagnostics or Becton Dickinson Monoclonal Center). In the case of illness (diarrhoea, oral thrush, or rash) microbiological studies of throat and stool cultures for infectious agents, urine cultures for cytomegalovirus, and cultures of cutaneous lesions for herpesviruses were done. Antibody to HIV was measured using a commercial enzyme immunoassay (Recombinant HIV 1 EIA, Abbott). HIV was cultured from peripheral blood mononuclear cells as described elsewhere. ${ }^{15}$ As the Brodt-Helm classification does not take account of the patient's age, ${ }^{16}$ it was used for analysis of progression (table 1). In addition this classification directs more attention to the helper cell count than the Centers for Disease Control (CDC) classifications.

During the study some patients received antibiotics and intravenous immunoglobulins. Zidovudine was given in three cases, thus fulfilling the CDC case definition of AIDS or being classified as CDC stage IV A.

Table 1 Brodt-Helm classification of HIV infection ${ }^{16}$

\begin{tabular}{ll}
\hline Stage & Definition \\
\hline la & Healthy, seronegative subject at risk of \\
HIV infection \\
1b & $\begin{array}{l}\text { Healthy, seropositive subject } \\
\text { Sa }\end{array}$ \\
Seropositive patients with lymphadenopathy \\
syndrome and a CD4:CD8 ratio between 0.5 \\
and 1.0 \\
Seropositive patients with severe \\
immunodeficiency and a CD4 \\
of $<350 / \mu l$ cell count \\
AIDS (CDC definition)
\end{tabular} \\ Department of \\ D Niese \\ Correspondence to:

University of Bonn,
Federal Republic
of Germany
Department of
Paediatrics
N Wagner
R Bialek
H Radinger
M Becker
Department of
Medical Microbiology
K E Schneweis
Department of
Experimental
Haematology
H H Brackmann
Department of
Internal Medicine
D Niese
Correspondence to:
Dr N Wagner,
Zentrum für Kinderheilkunde
der Universiät Bonn,
Adenauerallee 119,
D-5300 Bonn,
Federal Republic of Germany.
Accepted 13 July 1990


Table 2 Staging of HIV infection in 53 haemophilic children and adolescents at end of survey (15 December 1989)

\begin{tabular}{|c|c|c|c|c|c|}
\hline \multicolumn{2}{|c|}{$\begin{array}{l}C D C \text { classification for patients aged } \\
<13 \text { years }(n=10)\end{array}$} & \multicolumn{2}{|c|}{$\begin{array}{l}C D C \text { classification for patients aged } \\
\geqslant 13 \text { years }(n=43)\end{array}$} & \multicolumn{2}{|c|}{$\begin{array}{l}\text { Brodt-Helm classification } \\
(n=53)\end{array}$} \\
\hline Stage & No (No of deaths) & Stage & No (No of deaths) & Stage & No (No of deaths) \\
\hline $\begin{array}{l}\text { P1B } \\
\text { P2A }\end{array}$ & $\begin{array}{l}1(0) \\
9(1)\end{array}$ & $\begin{array}{l}\text { IIA } \\
\text { IIB } \\
\text { IIIA } \\
\text { IIIB } \\
\text { IVA } \\
\text { IVC }_{1} \\
\text { IVC }_{2} \\
\text { IVB }\end{array}$ & $\begin{array}{r}4(0) \\
1(0) \\
21(0) \\
11(0) \\
1 \quad(0) \\
2(0) \\
2(0) \\
1(1)\end{array}$ & $\begin{array}{l}1 b \\
2 a \\
2 b \\
3\end{array}$ & $\begin{array}{r}5(0) \\
29(0) \\
15(0) \\
4(2)\end{array}$ \\
\hline
\end{tabular}

\section{Results}

STAGING

The actual staging of the patients by the BrodtHelm method, and the CDC paediatric $(<13$ years old), and the CDC adult (13 years old or more) classifications is shown in table 2 . Two patients had died by the time of writing, one of an HIV associated wasting syndrome and another of a progressive multifocal leucoencephalopathy.

By December 1989, nine of the remaining patients were less than 13 years of age and 42 patients were between 13 and 20; the different CDC classifications were used according to age. Four of the five patients with haemophilia $B$ were classified as stage $2 a$, and one patient as stage lb (Brodt-Helm). ${ }^{16}$

\section{EVALUATION OF PROGRESSION}

During the period of evaluation 32 patients $(60 \%)$ deteriorated according to the Brodt-Helm classification, and two patients died of AIDS. The staging at the time of the first examination and after a mean observation time of $\mathbf{3 0}$ months is shown in table 3 .

CLINICAL SYMPTOMS

Table 4 shows the infections and other dis-

Table 3 Progression of disease during median evaluation period of 30 months by Brodt-Helm classification in 53 haemophilic patients with HIV infection

\begin{tabular}{lrlrlll}
\hline $\begin{array}{l}\text { Stage at first } \\
\text { examination }\end{array}$ & \multicolumn{2}{l}{$\begin{array}{l}\text { Stage at last } \\
\text { examination }\end{array}$} & & \multirow{2}{*}{$\begin{array}{l}\text { No who } \\
\text { died }\end{array}$} \\
\cline { 2 - 5 } & & $1 b$ & $2 a$ & $2 b$ & 3 & \\
\hline $1 \mathrm{~b}$ & 29 & 5 & 15 & 8 & 1 & 0 \\
$2 \mathrm{a}$ & 21 & 0 & 14 & 6 & 1 & 0 \\
$2 \mathrm{~b}$ & 2 & 0 & 0 & 1 & 1 & 1 \\
3 & 1 & 0 & 0 & 0 & 1 & 1
\end{tabular}

Table 4 Symptoms in 53 haemophilic patients with HIV infection

\begin{tabular}{ll}
\hline & $\begin{array}{l}\text { No of } \\
\text { patients }\end{array}$ \\
\hline $\begin{array}{l}\text { Recurrent infections (more than three infections } \\
\text { in six months, including otitis, sinusitis, and } \\
\text { bronchopulmonary infection) }\end{array}$ & \\
Herpes zoster & 8 \\
Oral candidiasis (not associated with antibiotic & 8 \\
treatment) & 4 \\
Bilateral tumour of the parotid gland & 3 \\
Pneumonia & 2 \\
HIV associated wasting syndrome* & 1 \\
Progressive multifocal leucoencephalopathy* & 1 \\
Toxoplasmosis chorioretinitis* & 1 \\
Pneumocystis carinii pneumonia* & 1 \\
Fever of unknown origin & 1 \\
Impetigo & 1 \\
\hline
\end{tabular}

*Diagnoses fulfilling CDC criteria for AIDS. orders that developed during the evaluation time. Four patients developed AIDS.

\section{LABORATORY TESTS}

The figure shows a comparison between the absolute count of $\mathrm{CD}^{+} \mathrm{T}$ cells and the percentage ratio of $\mathrm{CD}^{+} \mathrm{T}$ cells to total lymphocytes after a mean observation time of 18 months. Nineteen patients $(37 \%)$ had decreased absolute counts of helper cells ( $<500 \mathrm{CD}^{+} \mathrm{T}$ cells), whereas 45 patients $(87 \%)$ already had a lowered ratio of helper cells to lymphocytes $(<0 \cdot 35)$.

VIRUS CULTURE

In 46 patients blood samples were available in which we attempted to culture HIV from

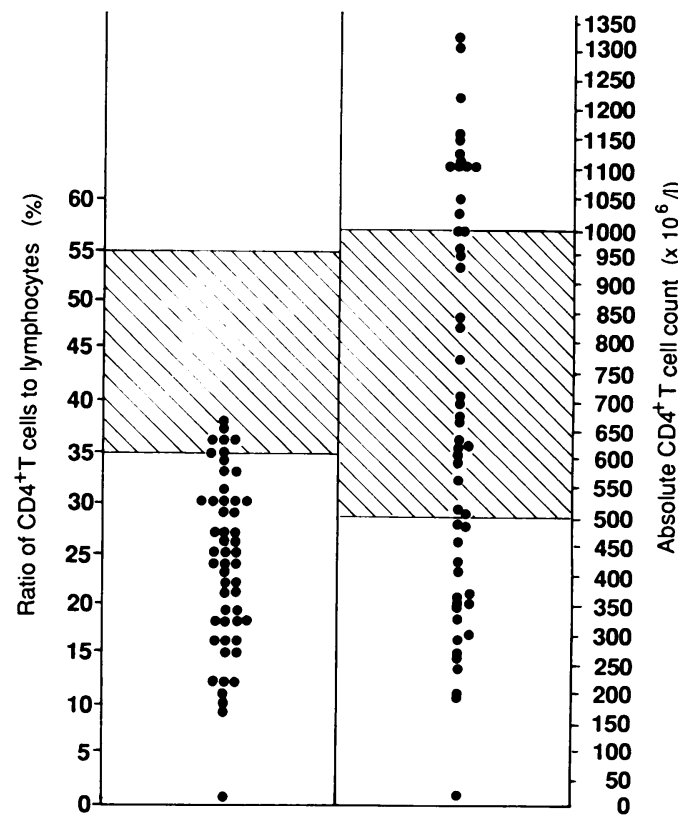

Distribution of the ratio of $\mathrm{CD4}^{+} \mathrm{T}$ cells:total lymphocytes $(n=52)$, and absolute $C D 4^{+} T$ cell count $(n=52)$ in haemophilic children and adolescents infected with HIV. The hatched area indicates the reference range.

Table 5 Positive HIV cultures of lymphocytes from peripheral blood correlated with Brodt-Helm staging in 46 haemophilic patients

\begin{tabular}{lcc}
\hline $\begin{array}{l}\text { Brodt-Helm } \\
\text { stage }\end{array}$ & $\begin{array}{l}\text { No of patients } \\
\text { tested }\end{array}$ & $\begin{array}{l}\text { No of cultures } \\
\text { positive for } \\
\text { HIV }\end{array}$ \\
\hline 1b & 2 & 0 \\
$2 \mathrm{a}$ & 31 & 18 \\
$2 \mathrm{~b}$ & $1 \mathrm{9}$ & 2 \\
\hline 3 & 2 & 29 \\
\hline Total & 46 &
\end{tabular}


peripheral blood mononuclear cells. In 12 patients the first cultures for HIV were negative, but HIV was detected in a subsequent test several months later. In 17 patients the first virus culture was positive, so HIV could be cultured in the mononuclear cells of a total of 29 of the 46 patients (63\%). If the virus culture was positive, repeated tests were also positive. The staging at the time of the first positive virus culture in these patients is shown in table 5 .

\section{Discussion}

EVALUATION OF STAGING AND PROGRESS

The mean latent period before the development of AIDS is many years. ${ }^{17}$ Primary infection with HIV in the patients in this study probably occurred between 1980 and 1983, before clotting factor concentrates that had been treated to inactivate viruses were introduced in 1984; their seroconversion was detected in 1984 and 1985. Most of the patients should therefore be in the latent state. This is confirmed by the actual staging six to 10 years after the probable date of primary infection (table 2). There are three patients in this study whose treatment was changed in 1981 to clotting factor concentrates that had been treated to inactivate viruses because of severe liver damage, so their HIV was probably inoculated before 1981. This might mean that these patients had HIV infection but had not developed AIDS for more than nine years. Haemophilic patients have, however, died of AIDS three years after inoculation of HIV (N Wagner, et al. Abstract presented at the IV Interational Conference on AIDS, Stockholm 1988). There is controversy about the course of HIV infection in haemophilic patients, particularly about the incubation period of AIDS or HIV related symptoms (P Becker, et al. Abstract presented at the IV International Conference on AIDS, Stockholm 1988; JK Stehr-Green, et al. Abstract presented at the IV International Conference on AIDS, Stockholm 1988). ${ }^{9-11} 18$ In this study progression of the disease has been shown during an observation time of $\mathbf{3 0}$ months, and it is comparable with the development of HIV infections in other risk groups (GW Rutherford, et al. Abstract presented at IV International Conference on AIDS, Stockholm 1988). ${ }^{16}$ In addition, immunological tests were abnormal in a larger number of patients with HIV after 18 months evaluation (figure) compared with haemophiliacs not infected with HIV (E Berntorp, et al. Abstract presented at XVIII International Congress of the World Federation of Haemophilia, Madrid 1988). ${ }^{19}$ These results might be early signs of immune deterioration. No difference in staging of HIV infection between the patients with haemophilia $A$ and the few with haemophilia B could be detected.

Recently Goedert et al reported a prospective study of the development of AIDS in a large cohort of haemophiliacs infected with HIV. Their findings showed that there was an age related risk for AIDS with a lower risk in the younger group (the incidence rate of AIDS after seroconversion was $0.83 / 100$ patient years in those who were 1 to 11 years old compared with 5.66 in those aged 35 to 70 years). ${ }^{20}$
The results of our study show a remarkable progression of HIV infection in haemophilic children and adolescents during a median period of 30 months, especially the transition from symptomless infection to lymphadenopathy syndrome, and to pronounced immunodeficiency with a $\mathrm{CD}^{+}$cell count of $<350 / \mu \mathrm{l}$. Whether there is a significant difference in the rate of progression compared with other risk groups (adult haemophiliacs, homosexual men, and drug addicts) cannot be concluded from these data. There is no doubt, however, that infants infected with HIV prenatally or perinatally often show progression of HIV related disease during the first year of life..$^{21-23}$

\section{CLINICAL SYMPTOMS}

Even before the development of AIDS, HIV infection is associated with a number of symptoms. In this study mild infectious diseases were often diagnosed. These findings are consistent with other studies, which also show the range of the early stages of a paediatric HIV infection. ${ }^{24-26} \mathrm{~A}$ remarkable number of cases with herpes zoster was found. This could be of clinical importance, as infections with herpesviruses may act as cofactors in HIV infection. ${ }^{27}$

\section{LABORATORY TESTS}

The absolute number of helper cells is of clinical importance, as there will be a high risk of opportunistic infections if the $\mathrm{CD}^{+} \mathrm{T}$ cell count is below $150 / \mu \mathrm{l} .{ }^{28}$ The ratio of helper cells to total lymphocytes (this is not the CD4:CD8 ratio but the CD4:total lymphocyte ratio) has been shown to be a prognostic indicator (JV Giorgi, et al. Abstract presented on the IV International Conference on AIDS, Stockholm 1988). ${ }^{10}$ The predictive value of the absolute count of helper cells is limited, as both the total and the differential white cell count and flow cytometry are necessary for calculating the absolute number of $\mathrm{CD4}^{+}$cells. The total and differential white cell counts, however, vary with non-specific infections. As a consequence, the absolute helper cell count does not seem to be useful as an early predictive sign of an initial deterioration of the immune system in HIV infection.

In our experience, however, the ratio of helper cells to lymphocytes varies less than the absolute helper cell count, confirming the work of other authors. ${ }^{29}$ Moreover, in the patients of this study subnormal $\mathrm{CD}^{+}{ }^{+} \mathrm{T}$ cell to lymphocyte ratios were seen earlier in HIV infection than those of the absolute $\mathrm{CD}^{+}{ }^{+} \mathrm{T}$ cell count (figure). Altogether $37 \%$ of the patients showed an absolute helper cell count of less than 500 cells $/ \mu \mathrm{l}$, whereas $87 \%$ of the patients had a decreased ratio of CD4 cell:lymphocytes of less than 0.35 after a median evaluation period of 18 months. This is, of course, partly a result of the reactive increase in $\mathrm{CD}^{+} \mathrm{T}$ cells. A.ratio of less than 0.25 may, however, be a negative prognostic sign for patients who still have absolute helper cell counts within the normal range. This hypothesis will be studied by evaluation of progression in the future. 
Another important indicator of progression of HIV infection is the results of virus cultures. ${ }^{30}$ Despite the low number of positive virus cultures reported here, the rate seems to increase as the disease progresses. This is in accordance with the results of other investigations. ${ }^{31}$

This study was supported by the Bundesministerium für Arbeit, Federal Republic of Germany.

1 Blanche S, Deist FC, Fischer A, et al. Longitudinal study of 18 children with perinatal LAV/HTLV III infection: attempt at a prognostic evaluation. $\mathcal{J}$ Pediatr 1986;109:96570.

2 Borkowsky W, Krasinski K, Paul D, et al. Human immunodeficiency virus infections in infants negative for anti-HIV by enzyme linked immunoassay. Lancet 1987;i:1168-71.

3 Sailsbury FT, Wykoff RF, Boyle RJ. Transfusion acquired human immunodeficiency virus infection in twelve neonhuman immunodeficiency virus infection in twelve neon-
ates; epidemiologic, clinical and immunological features. ates; epidemiologic, clinical and im

4 Toro PA, de Martino M. Epidemiology, clinical features and prognostic factors of paediatric HIV infection. Lance 1988; i: $1043-5$

5 Johnson RE, Lawrence DN, Evatt BL, et al. Acquired immunodeficiency syndrome among patients attending hemophilia treatment centers and mortality experience of hemophiliacs in the United States. Am $\mathcal{J}$ Epidemiol 1985;121:797-809.

6 Rogers MF, Thomas PH, Starcker ET, Noa MC, Bush TJ, Jaffe HW. Acquired immunodeficiency syndrome in children: report of the Centers for Disease Control National Surveillance, 1982-1985. Pediatrics 1987;79:1008-14.

7 Krasinski K, Borkowsky W, Holzman RS. Prognosis of human immunodeficiency virus infection in children and adolescents. Pediatr Infect Dis $\mathcal{F}$ 1989;8:216-20.

8 Rothenberg R, Woelfel M, Stoneburner R, Milberg J, Parker R, Truman B. Survival with the acquired immunodeficiency syndrome. Experience with 5833 cases in New York ciency syndrome. Experience with 5833 cases

9 Hilgartner MW. AIDS and hemophilia. N Engl f Med 1987;317:1153-4.

10 Jason JM, Stehr-Green J, Holman RC, Evatt BL. Human immunodeficiency virus infection in hemophilic children. Pediatrics 1988;82:565-70.

11 Teitel JM, Freedman JJ, Garvey MB, Kardish M. Two year evaluation of clinical and laboratory variables of immune function in 117 hemophiliacs seropositive or seronegative for HIV-1. Am $\mathcal{F}$ Hematol 1989;32:262-72.

12 Allain JP, Laurian Y, Paul DA, et al. Long-term evaluation of HIV antigen and antibodies to 24 and gp 41 in patients with hemophilia. $N$ Engl f Med 1987;317:1114-21.

13 Giesecke J, Scalia-Tomba G, Berntorp E, Schulman S, Stigendal L. Incidence of symptoms and AIDS in 146 Swedish haemophiliacs and blood transfusion recipients infected with human immunodeficiency virus. Br Med $\mathcal{f}$ with human im
14 Lee CA, Phillips A, Elford J, et al. The natural history of human immunodeficiency virus infection in a haemophilic cohort. Br $\mathcal{F}$ Haematol 1989;73:228-34.

15 Schneweis KE, Ackermann A, Friedrich A, Klein JP, Ruff R, Siefer-Wippermann B. Comparison of different methods for detecting human immune deficiency virus in human immunodeficiency virus-seropositive hemophiliacs. $\mathcal{f}$ Med Virol 1989;29:94-101.

16 Brodt HR, Helm EB, Werner A, et al. Spontaneous course of LAV/HTLV III infection. Disch Med Wochenschr 1986;111:1175-80.

17 Jaffe HW, Darrow WW, Echenberg DF, et al. The acquired immunodeficiency syndrome in a cohort of homosexual immunodeficiency syndrome in a coho
men. Ann Intern Med 1985;103:210-5.

18 Rees $M$. AIDS incubation period in haemophiliacs. Nature 1988;332:312.

19 Sullivan JL, Brewster FE, Brettler DB, et al. Hemophiliac immunodeficiency: influence of exposure to factor VIII concentrate, LAV/HTLV III and herpes viruses. I Pediatr 1986;108:504-10.

20 Goedert JJ, Kessler CM, Aledort LM, et al. A prospective study of human immunodeficiency virus type 1 infection and the development of AIDS in subjects with hemophilia. $N$ Engl f Med 1989;321:1141-8.

21 Blanche S, Rouzioux C, Guihard Moscato ML, et al. A prospective study of infants born to women seropositive for human immunodeficiency virus type $1 . N$ Engl $f$ Med 1989;320:1643-8.

22 Ryder RW, Nsa W, Hassig SE, et al. Perinatal transmission of the human immunodeficiency virus type 1 to infants of of the human immunodeficiency virus type 1 to infants of seropositive wom

23 Scott GB, Hutto C, Makuch RW, et al. Survival in children with perinatally acquired human immunodeficiency virus type 1 infection. N Engl f Med 1989;321:1791-6.

24 Kamani N, Lightman H, Leiderman J, Krilov LR. Pediatric acquired immunodeficiency syndrome-related complex: clinical and immunological features. Pediatr Infect Dis $\mathcal{F}$ 1988;7:383-8.

25 Krasinski K, Borkowski W, Bonk S, Lawrence R, Chandwani S. Bacterial infections in human immunodeficiency virus-infected children. Pediatr Infect Dis F 1988;7:323-8.

26 Pahwa S, Kaplan M, Fikrig S, et al. Spectrum of human Tcell lymphotropic virus type III infection in children. cell lymphotropic virus type

27 Mosca JD, Bednarik DP, Raj NBK, Pitha PM. Is there a role for herpesvirus in AIDS? Nature 1988;331:122.

28 Phair J, Munoz A, Detels R, Kaslow R, Rinaldo C, Saah A. The risk of pneumocystis carinii pneumonia among men with human immunodeficiency virus type 1 . N Engl $\mathcal{F}$ Med 1990;322:161-5.

29 Fahey JL, Taylor JMG, Detels R, et al. The prognostic value of cellular and serologic markers in infection with human immunodeficiency virus type $1 . N E n g l \quad f$ Med 1990;322:166-72.

30 Spira TJ, Kaplan JE, Feorino PM, Warfield DT, Fishbein DB, Bozemann LH. Human immunodeficiency virus viremia as a prognostic indicator in homosexual men with lymphadenopathy syndrome. $N$ Engl $\mathcal{F}$ Med 1987;317:1093-4.

31 Andrews CA, Sullivan JL, Brettler DB, et al Isolation of human immunodeficiency virus from hemophiliacs: correlation with clinical symptoms and immunologic abnormalities. F Pediatr 1987;111:672-7. 